University of Nebraska - Lincoln

DigitalCommons@University of Nebraska - Lincoln

\title{
CQESTR Simulated Changes in Soil Organic Carbon under Residue Management Practices in Continuous Corn Systems
}

\author{
Brian J. Wienhold \\ USDA-ARS, Brian.Wienhold@ars.usda.gov \\ Marty R. Schmer \\ USDA-ARS, marty.schmer@ars.usda.gov \\ Virginia L. Jin \\ USDA-ARS, virginia.jin@ars.usda.gov \\ Gary E. Varvel \\ USDA-ARS, gevarvel@windstream.net \\ Hero Gollany \\ USDA-ARS, hero.gollany@ars.usda.gov
}

Follow this and additional works at: https://digitalcommons.unl.edu/usdaarsfacpub

Wienhold, Brian J.; Schmer, Marty R.; Jin, Virginia L.; Varvel, Gary E.; and Gollany, Hero, "CQESTR Simulated Changes in Soil Organic Carbon under Residue Management Practices in Continuous Corn Systems" (2016). Publications from USDA-ARS / UNL Faculty. 1784.

https://digitalcommons.unl.edu/usdaarsfacpub/1784

This Article is brought to you for free and open access by the U.S. Department of Agriculture: Agricultural Research Service, Lincoln, Nebraska at DigitalCommons@University of Nebraska - Lincoln. It has been accepted for inclusion in Publications from USDA-ARS / UNL Faculty by an authorized administrator of DigitalCommons@University of Nebraska - Lincoln. 


\title{
CQESTR Simulated Changes in Soil Organic Carbon under Residue Management Practices in Continuous Corn Systems
}

\author{
Brian J. Wienhold ${ }^{1}$ - Marty R. Schmer ${ }^{1}$ - Virginia L. Jin ${ }^{1}$ - Gary E. Varvel ${ }^{2}$. \\ Hero Gollany ${ }^{3}$
}

Published online: 21 July 2015

(C) Springer Science+Business Media New York (outside the USA) 2015

\begin{abstract}
Soil organic carbon (SOC) is an important soil property and is strongly influenced by management. Changes in SOC stocks are difficult to measure through direct sampling, requiring both long time periods and intensive sampling to detect small changes in the large, highly variable pool. Models have the potential to predict management-induced changes in SOC stocks, but require long-term data sets for validation. CQESTR is a processedbased $\mathrm{C}$ model that uses site weather, management, and crop data to estimate changes in SOC stocks. Crop residue
\end{abstract}

The U.S. Department of Agriculture (USDA) prohibits discrimination in all its programs and activities on the basis of race, color, national origin, age, disability, and where applicable, sex, marital status, familial status, parental status, religion, sexual orientation, genetic information, political beliefs, reprisal, or because all or part of an individual's income is derived from any public assistance program. (Not all prohibited bases apply to all programs.) Persons with disabilities who require alternative means for communication of program information (Braille, large print, audiotape, etc.) should contact USDA's TARGET Center at (202) 720-2600 (voice and TDD). To file a complaint of discrimination, write to USDA, Director, Office of Civil Rights, 1400 Independence Avenue, S.W., Washington, D.C. 20250-9410, or call (800) 795-3272 (voice) or (202) 720-6382 (TDD). USDA is an equal opportunity provider and employer.

Mention of trade names or commercial products in this publication does not imply recommendation or endorsement by the U.S. Department of Agriculture.

Brian J. Wienhold

brian.wienhold@ars.usda.gov

1 Agroecosystem Management Research Unit, USDA-ARS, Rm 137 Keim Hall UNL-East Campus, Lincoln, NE 68583, USA

2 Agroecosystem Management Research Unit, Retired USDA-ARS, 137 Keim Hall, East Campus, UNL, Lincoln, NE 68583, USA

3 Columbia Plateau Conservation Research Center, USDA-ARS, P.O. Box 370, Pendleton, OR 97801, USA removal for livestock feed or future biofuel feedstock use is a management practice that potentially affects SOC stocks. Simulated changes in SOC using CQESTR were compared to measured SOC changes over 10 years for two contrasting residue removal studies in eastern Nebraska. The rainfed study compared SOC changes in no-tillage continuous corn grown under two $\mathrm{N}$ fertilizer rates (120 or $180 \mathrm{~kg} \mathrm{~N} \mathrm{ha}^{-1}$ ) and two residue removal rates ( 0 or $50 \%)$. The irrigated study compared SOC changes in continuous corn grown under no-tillage or disk tillage and three residue removal rates $(0,35$, or $70 \%)$. After 10 years under these management scenarios, CQESTR-estimated SOC stocks agreed well with the measured SOC stocks at both sites $\left(r^{2}=\right.$ 0.93 at the rainfed site and $r^{2}=0.82$ at the irrigated site). These results are consistent with other CQESTR validation studies and demonstrate that this process-based model can be a suitable tool for supporting current management and long-term planning decisions.

Keywords Maize $\cdot$ Nebraska $\cdot$ Feedstock $\cdot$ Soil quality . Irrigation $\cdot$ Tillage $\cdot \mathrm{N}$ fertilization

\section{Abbreviations \\ SOC Soil organic carbon \\ MSD Mean squared deviation}

\section{Introduction}

Demand for food, feed, fiber, and energy is increasing to support the growing human population. Meeting these demands will require intensification in management as well as genetic improvements in the crops that we grow [1-3]. Over the long term, the sustainability of crop production will require that 
changes in management do not degrade the soil resource. Management can impact numerous soil properties which affect soil fertility and crop productivity. Process-based models that accurately predict future management-induced changes in soil properties are needed to guide current agronomic decisions. A computer model that simultaneously predicts management impacts on the physical, chemical, and biological soil properties affecting crop production, however, does not exist, so sampling and measurement will continue to be necessary. Nonetheless, there is a general consensus that soil organic carbon (SOC) is a critical indicator of soil quality and linked to many agroecosystem functions $[4,5]$. The importance of SOC in affecting soil physical properties (e.g., structure and bulk density), chemical properties (e.g., nutrient availability and storage), and biological properties (e.g., energy and nutrient availability for soil biota) is well documented. In addition, $\mathrm{SOC}$ is responsive to management $[6,7]$. Unfortunately, management-induced changes to SOC are difficult to measure, often requiring long-time periods to detect small changes in a large and spatially variable SOC pool [8].

Process-based SOC models have potential as planning and assessment tools. Models can be used to compare management scenarios for their impact on SOC stocks. It is important that models be validated across a range of management practices and environmental conditions to ensure that they accurately predict the properties of interest. CQESTR is a processbased SOC model that relates crop residue additions and agronomic management to changes in SOC $[9,10]$. CQESTR has been validated using long-term data ( 20 to $>100$ years) from a number of locations (Illinois, Missouri, Nebraska, Colorado, Saskatchewan, and Alberta) in North America $[9,11$, 12]. CQESTR's ability to estimate residue removal impacts on SOC in tilled systems has also been validated [11, 13]. Previous validation of CQESTR has been limited to a maximum depth of $60 \mathrm{~cm}$, but management effects on SOC stocks that are deeper in the soil profile have been documented [14, 15] suggesting validation using data for greater soil depths is needed. Irrigation results in increased productivity and decomposition rates when compared to rainfed systems [16, 17], but CQESTR has not been validated in irrigated systems. There is a need for further validation to include management practices such as no-tillage, irrigation, and residue removal in other regions of the USA.

Crop residues (e.g., corn [Zea mays L.] stover and wheat [Triticum aestivum L.] straw) have been identified as the largest current source of feedstock for biofuel production [18] and are currently used extensively for livestock feed and bedding [19]. In response to concerns about large-scale removal of crop residue for these uses [20], levels of residue retention needed for soil conservation have been proposed [20-22] and amelioration practices have been identified [11, 23]. Unfortunately, soil response to management is site-specific or even subfield-specific [24] and general recommendations for residue removal rates are of limited use [25]. Because the magnitude and direction of SOC stocks change will likely be affected by the level of biomass inputs, type of residue, climate, and initial SOC content of the site [26,27], a processbased model that accurately predicts soil response to management across a range of conditions and practices is needed to guide agronomic decisions related to residue management.

The objective of this study was to use contrasting crop production and management data from two ongoing residue removal studies in eastern Nebraska (NE) to compare CQES TR-simulated SOC changes to measured changes after 10 years. The rainfed no-tillage site [14] included residue removal rate and $\mathrm{N}$ fertilization rate as treatment variables while the irrigated site [28] included residue removal rate and tillage intensity as treatment variables. Testing CQESTR at these two sites increases the range of management practices under which the model has been assessed to include irrigation, residue removal rates, tillage intensity, and differences in initial SOC stocks.

\section{Materials and Methods}

Two field sites located at the University of Nebraska Agricultural Research and Development Center near Ithaca, NE were used in this study. At this location (1981-2010), mean annual precipitation is $740 \mathrm{~mm}$ and mean annual temperature is $9.8^{\circ} \mathrm{C}$.

The experiment at the rainfed site was no-tillage continuous corn established in 1998 with residue removal treatments beginning in $2001[14,29]$. The site was previously in sorghum [Sorghum bicolor (L.) Moench] and soybean [Glycine $\max ($ L.) Merr.] crop rotation under conventional disk-tillage practices. Soils at the site are Yutan silty clay loam (fine-silty, mixed, superactive, mesic, Mollic Hapludalf) and Tomek silt loam (fine, smectitic, mesic, Pachic Argiudoll). The experiment was arranged in a randomized blocks $(N=3)$ split plot design where $\mathrm{N}$ fertilizer rate $\left(60,120\right.$, or $\left.180 \mathrm{~kg} \mathrm{~N} \mathrm{ha}^{-1}\right)$ was the main plot and residue removal rate $(0$ or $50 \%)$ was the subplot. The $0 \%$ removal rate was used as a no-residue removal control and the $50 \%$ rate represents the maximum amount of residue that can be removed with a flail chopper without disturbing the soil. Results from only 120 and $180 \mathrm{~kg} \mathrm{~N} \mathrm{ha}^{-1}$ treatments are presented here as representative of local producer practice. Glyphosate-tolerant hybrids adapted to the region were sown at 47,700 seeds $\mathrm{ha}^{-1}$ in $0.76 \mathrm{~cm}$ rows. Fertilizer $\mathrm{N}$ was surface applied as ammonium nitrate $\left(\mathrm{NH}_{4} \mathrm{NO}_{3}\right)$ at the beginning of the growing season until 2007, after which $\mathrm{N}$ was applied at V6 as urea (46-00-00) knifed in at a depth of $10-15 \mathrm{~cm}$ in subsequent years. At physiological maturity (September to early October), grain was combine harvested. In the stover removal subplot, residue was removed using a flail chopper with a weigh wagon. The 
chopper was set at a height of $10 \mathrm{~cm}$ to maximize residue removal and minimize soil surface disturbance.

The experiment at the irrigated site was continuous corn established in 2001 in a field under rainfed corn the previous year [28]. Soils at this site are a Tomek silt loam (fine, smectitic, mesic Pachic Argiudoll) and a Filbert silt loam (fine, smectitic, mesic Vertic Argialboll). The experiment was arranged in a randomized blocks $(N=6)$ split-plot design where tillage treatment (no-tillage vs disk tillage to a depth of $20 \mathrm{~cm}$ ) was the main plot and residue removal rate $(0,35$, and $70 \%)$ was the subplot. Residue in high production irrigated corn systems interferes with planting and stand establishment in subsequent years. The $0 \%$ removal rate was selected as a no-residue removal control, the $35 \%$ removal rate was selected as a treatment that would reduce the potential for interfering with planting and stand establishment, and the $70 \%$ removal rate was selected as the maximum amount of residue that can be removed with a flail chopper without disturbing the soil. Glyphosate-tolerant corn hybrids adapted to the region were sown at 74,000 seeds $\mathrm{ha}^{-1}$ in $0.76 \mathrm{~cm}$ rows. Fertilizer $\mathrm{N}$ was surface applied as $\mathrm{NH}_{4} \mathrm{NO}_{3}$ at the beginning of the growing season until 2007, after which $\mathrm{N}$ was applied at V6 as urea knifed in at a depth of $10-15 \mathrm{~cm}$ in subsequent years. Irrigation was provided using a solid set system in 2001 and through a linear-move system from 2002 to present. Irrigation averaged $12.5 \pm 7.0 \mathrm{~cm}$ from 2001 to 2010 . At physiological maturity (September to early October), grain was combine harvested. Stover was removed using a flail chopper with a weigh wagon. The chopper was set at a height of $10 \mathrm{~cm}$ to maximize residue removal and minimize soil surface disturbance. The $70 \%$ removal rate being achieved by harvesting all rows and the $35 \%$ removal rate being achieved by harvesting every other two rows in alternating years (i.e., unharvested rows in one year were harvested the subsequent year).

Soil samples were collected at the initiation of each experiment and again after 10 years for determination of texture, bulk density, and organic $\mathrm{C}$ concentration. At the rainfed site, cores were segmented into 0 to 10,10 to 30,30 to 60,60 to 90 , and 90 to $120 \mathrm{~cm}$ increments. At the irrigated site, cores were segmented into 0 to 15,15 to 30,30 to 60,60 to 90 , and 90 to $120 \mathrm{~cm}$ increments. For each depth increment, soil bulk density was determined using the sample volume and oven dry $\left(105^{\circ} \mathrm{C}\right)$ mass of soil [30]. A subsample of field moist soil was passed through a $2 \mathrm{~mm}$ sieve, dried at $55^{\circ} \mathrm{C}$, ground to pass a $150-\mu \mathrm{m}$ sieve, and $\mathrm{C}$ and $\mathrm{N}$ concentration determined by dry combustion [31]. Soil organic C content was calculated using measured bulk density, $\mathrm{C}$ concentration, and soil depth increment thickness and then summed over all layers. Follett et al. [14] found no difference in SOC stocks which were nonadjusted or adjusted for equivalent soil mass due to high field variability at the rainfed site. Because variability at the irrigated site was comparably high, non-adjusted $\mathrm{Mg} \mathrm{C}$ per hectare was also used at the irrigated site [28]. To allow comparison between modeled results and previously published results, non-adjusted SOC were also used in this study. While both studies are ongoing, validation of CQESTR was limited to the time period corresponding to previously published weather, management data, and measured changes in SOC $[14,28]$.

Changes in SOC stocks were predicted with CQESTR by creating Revised Universal Soil Loss Equation (RUSLE, Version 1, [32]) C-factor crop management files using grain and biomass yields, residue removal rates previously reported [14, 28, 29], and management information described above. Soil data files were created with texture and initial $\mathrm{C}$ concentration for depth increments corresponding to those described above. A simulation period of 20 years was used, and the model output for the 10-year period from years 5 to 15 was used to assess management effects on SOC stocks. The spin-up procedure, allowing the model to run for several years before beginning the assessment, is a common practice that ensures SOC pools are established and model artifacts are avoided $[33,34]$.

Model output was validated by regressing CQESTR simulated SOC and measured SOC reported by Follett et al. [14] and Schmer et al. [28] and decomposing the mean squared deviation (MSD) into squared bias, non-unity slope, and lack of correlation components [35]. The MSD is proposed to directly measure predictive success of a model, where the sum of the three component values equals the MSD: squared bias evaluates "translation" of the regression (i.e., slope $b=1$ and intercept $a \neq 0$ ), non-unity slope evaluates "rotation" of the regression (i.e., slope $b \neq 1$ ), and lack of correlation evaluates "scatter" about the regression (i.e., $r^{2} \neq 1$ ). Validated model output was analyzed using a general linear model (SAS; PROC GLIMMIX) appropriate for a split-plot design [36]. This analysis was done to assess if treatment comparisons of simulated data agreed with those reported for the measured data $[14,28]$. At the rainfed site, fertilizer $\mathrm{N}$ rate (main plot) and residue removal (sub-plot) were considered fixed effects, block a random effect, and year a repeated measure. At the irrigated site, tillage (main plot) and residue removal (subplot) were considered fixed effects, block a random effect, and year a repeated measure. The analysis of variance was run for simulated SOC by soil layer and by cumulative soil depth. Treatment effects and interactions were assessed using least-square means at $P \leq 0.05$.

\section{Results}

At both sites, CQESTR-simulated SOC content agreed well with measured SOC content after ten years (Fig. 1). At the rainfed site, $66 \%$ of the MSD was attributed to lack of correlation due to scatter and $33 \%$ was attributed to squared bias due to lack of translation (Fig. 2). At the irrigated site, over $95 \%$ of the MSD was attributed to lack of correlation due to 


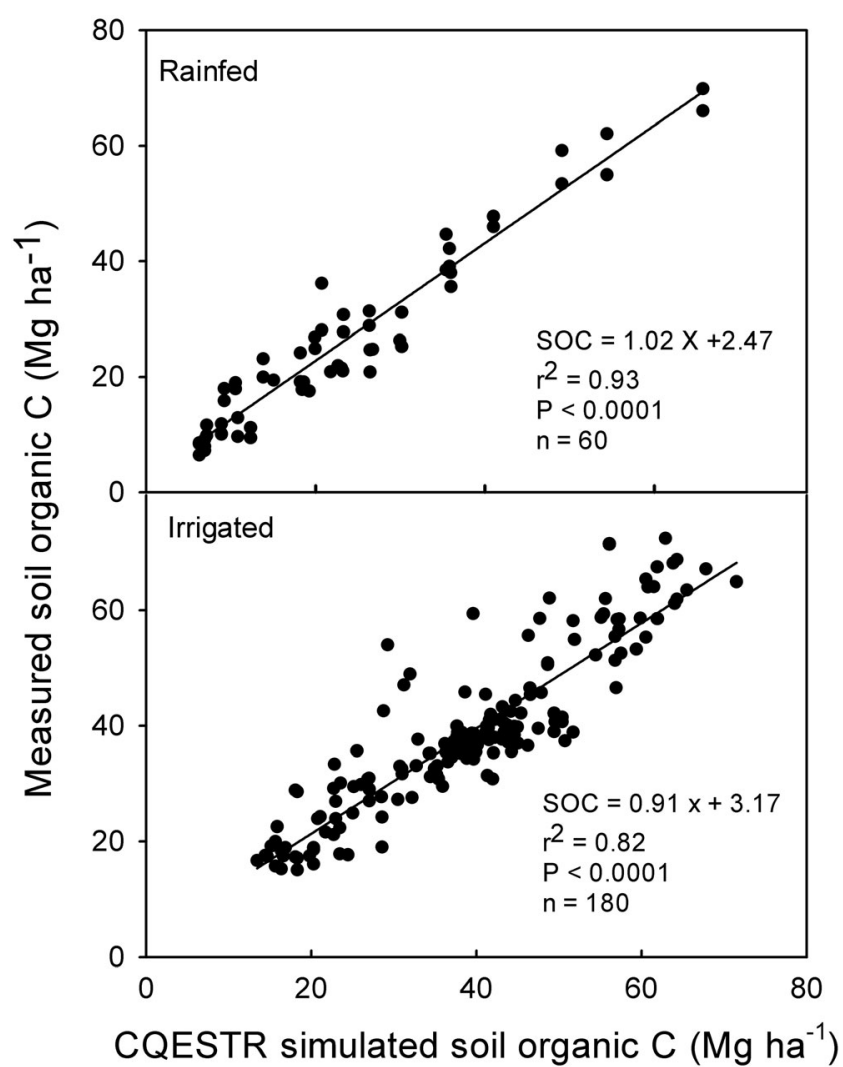

Fig. 1 Relationship between CQESTR simulated and measured soil organic C (SOC) after 10 years at two sites in eastern Nebraska. Each dot represents SOC for a depth increment of a treatment plot

scatter and $4 \%$ to non-unity slope due to rotation (Fig. 2). For the irrigated site, a large number of the points that are displaced from the regression line represent samples from the 30 to 60 and 60 to $90 \mathrm{~cm}$ depth increments. Measured initial SOC in these two depth increments exhibited greater variation than other depth increments. Hence, variation in

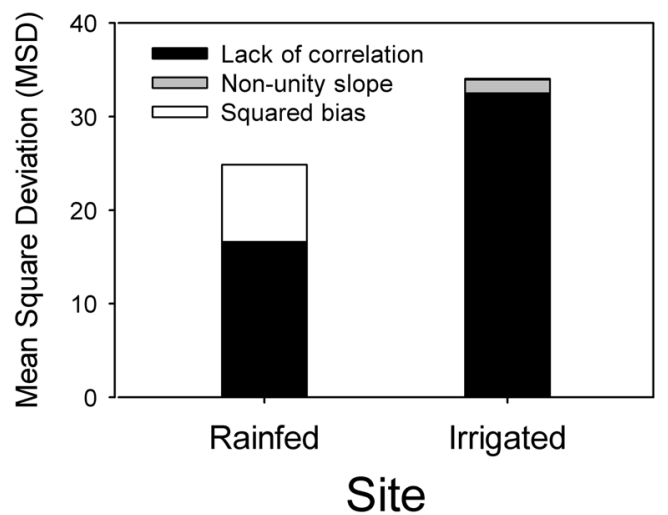

Fig. 2 Mean squared deviation (MSD) for the relationship between CQESTR simulated and measured soil organic C (SOC) after 10 years at two sites in eastern Nebraska. Total bar height represents the MSD which proposed to directly measure predictive success of a model. The bar segments decompose the MSD into squared bias (translation of the regression, i.e., slope $b=1$, intercept $a \neq 0$ ), non-unity slope (rotation of the regression, i.e., slope $b \neq 1$ ), and lack of correlation (scatter about the regression, i.e., $r^{2} \neq 1$ ) components [35] initial values (used by the model) contributed to variation in modeled final results.

At the rainfed site, simulated SOC content increased from 1998 to 2007 in the 0 to $10 \mathrm{~cm}$ increment (Table 1). Over this time period, there were greater increases in the high $\mathrm{N}$ treatment than the low $\mathrm{N}$ treatment (significant $\mathrm{N}$-rate by year interaction) and greater increases with no residue removal than with residue removal (significant removal by year interaction). There were no changes in SOC content in the 10 to $30 \mathrm{~cm}$ increment. In the 30 to $60 \mathrm{~cm}$ increment, SOC content decreased with greater losses in the low $\mathrm{N}$ treatment than in the high $\mathrm{N}$ treatment (significant $\mathrm{N}$ rate by year interaction). There was no change in SOC content in the 60 to 90 and 90 to $120 \mathrm{~cm}$ increments.

At the rainfed site, cumulative changes in simulated SOC content with depth all exhibited a significant removal by year interaction (Table 1). As noted above, increases in SOC content in the 0 to $10 \mathrm{~cm}$ increment were greater with no residue removal than with residue removal. A similar response was observed for cumulative SOC content from 0 to $30 \mathrm{~cm}$. Cumulative SOC content from 0 to 60,0 to 90 , or 0 to $120 \mathrm{~cm}$ exhibited small increases with no residue removal and no change over 10 years with residue removal.

At the irrigated site, simulated SOC content increased from 2001 to 2010 in the 0 to $15 \mathrm{~cm}$ increment (Table 2). Over this time period, increases were greater with no-tillage than with disk tillage. Within tillage treatments, less increase in SOC content were predicted with increasing rates of residue removal (significant tillage by residue removal by year effect). In the 15 to $30 \mathrm{~cm}$ increment, $\mathrm{SOC}$ content decreased to a greater extent in no-tillage with 0 or $70 \%$ removal than in disk tillage with 0 or $70 \%$ removal, but SOC losses were greater in disk tillage with $35 \%$ removal than in no-tillage with $35 \%$ removal (very significant tillage by residue removal by year interaction). In the 30 to 60,60 to 90 , and 90 to $120 \mathrm{~cm}$ depth increments, there was a decrease in SOC content from 2001 to 2010 with no differences among treatments (significant year effect).

At the irrigated site, cumulative changes with depth in simulated SOC content exhibited significant tillage treatment by residue removal by year interactions (Table 2). Changes in SOC content in the 0 to $15 \mathrm{~cm}$ increment were described above. With disk tillage, SOC content did not change in the 0 to $30 \mathrm{~cm}$ increment, while with no-tillage SOC content increased in the following order of residue removal rates: $70 \%<0 \%<35 \%$. In the 0 to 60,0 to 90 , and 0 to $120 \mathrm{~cm}$ increments, SOC content decreased from 2001 to 2010 under disk tillage with similar decreases across residue removal rates. In the 0 to $60 \mathrm{~cm}$ increment under no-tillage, there was a slight change in SOC content from 2001 to 2010 with residue removal. The SOC content increased by $0.9 \mathrm{Mg} \mathrm{ha}^{-1}$ without residue removal while it decreased by $0.9 \mathrm{Mg} \mathrm{ha}^{-1}$ with $70 \%$ residue 
Table 1 CQESTR-simulated initial and final soil organic carbon (SOC) content (mean \pm SEM) by nitrogen $(\mathrm{N})$ and residue removal treatments for a rainfed continuous corn site in eastern Nebraska

\begin{tabular}{|c|c|c|c|c|c|c|c|c|c|c|c|}
\hline \multirow{3}{*}{$\begin{array}{l}\mathrm{N} \text { rate } \\
\left(\mathrm{kg} \mathrm{ha}^{-1}\right)\end{array}$} & \multirow[t]{3}{*}{ Residue removed (\%) } & \multicolumn{10}{|l|}{ Year } \\
\hline & & & \multicolumn{9}{|c|}{ Soil depth increment $(\mathrm{cm})$} \\
\hline & & & 0 to 10 & 10 to 30 & 30 to 60 & 60 to 90 & 90 to 120 & 0 to 30 & 0 to 60 & 0 to 90 & 0 to 120 \\
\hline & & & \multicolumn{9}{|c|}{ Soil organic carbon $\left(\mathrm{Mg} \mathrm{C} \mathrm{ha}^{-1}\right)$} \\
\hline \multirow[t]{6}{*}{120} & $0 \%$ & 1998 & $19.4 \pm 2.5$ & $30.5 \pm 3.8$ & $33.2 \pm 18.3$ & $26.2 \pm 15.8$ & $18.9 \pm 12.3$ & $49.9 \pm 6.4$ & $83.1 \pm 23.5$ & $109.2 \pm 39.2$ & $128.2 \pm 51.5$ \\
\hline & & 2007 & $26.0 \pm 2.4$ & $29.8 \pm 3.6$ & $31.5 \pm 17.3$ & $24.7 \pm 14.9$ & $17.8 \pm 11.6$ & $55.8 \pm 6.0$ & $87.3 \pm 22.1$ & $112.0 \pm 37.0$ & $129.8 \pm 48.5$ \\
\hline & & $\% \Delta$ & 25.6 & -2.6 & -5.4 & -6.0 & -6.1 & 10.6 & 4.8 & 2.4 & 1.3 \\
\hline & $50 \%$ & 1998 & $19.4 \pm 2.5$ & $30.5 \pm 3.8$ & $33.2 \pm 18.3$ & $26.2 \pm 15.8$ & $18.9 \pm 12.3$ & $49.9 \pm 6.4$ & $83.1 \pm 23.5$ & $109.2 \pm 39.2$ & $128.2 \pm 51.5$ \\
\hline & & 2007 & $22.8 \pm 2.4$ & $29.8 \pm 3.6$ & $31.5 \pm 17.3$ & $24.7 \pm 14.9$ & $17.8 \pm 11.6$ & $52.6 \pm 6.0$ & $84.1 \pm 22.1$ & $108.8 \pm 37.0$ & $126.6 \pm 48.5$ \\
\hline & & $\% \Delta$ & 15.2 & -2.6 & -5.4 & -6.0 & -6.1 & 5.1 & 1.2 & -0.4 & -1.2 \\
\hline \multirow[t]{6}{*}{180} & $0 \%$ & 1998 & $15.5 \pm 2.5$ & $28.0 \pm 5.0$ & $25.3 \pm 13.4$ & $20.0 \pm 8.8$ & $12.3 \pm 4.8$ & $43.6 \pm 7.4$ & $68.8 \pm 20.5$ & $88.8 \pm 28.9$ & $101.1 \pm 33.8$ \\
\hline & & 2007 & $22.5 \pm 2.3$ & $27.4 \pm 4.7$ & $24.0 \pm 12.6$ & $18.9 \pm 8.3$ & $11.6 \pm 4.6$ & $49.9 \pm 7.0$ & $73.9 \pm 19.3$ & $92.8 \pm 27.2$ & $104.4 \pm 31.8$ \\
\hline & & $\% \Delta$ & 31.0 & -2.3 & -5.2 & -6.0 & -6.1 & 12.7 & 6.9 & 4.3 & 3.1 \\
\hline & $50 \%$ & 1998 & $15.5 \pm 2.5$ & $28.0 \pm 5.0$ & $25.3 \pm 13.4$ & $19.4 \pm 9.2$ & $12.2 \pm 4.9$ & $43.6 \pm 7.4$ & $68.8 \pm 20.5$ & $88.2 \pm 29.2$ & $100.4 \pm 34.0$ \\
\hline & & 2007 & $19.1 \pm 2.3$ & $27.4 \pm 4.7$ & $24.0 \pm 12.6$ & $18.3 \pm 8.7$ & $11.5 \pm 4.6$ & $46.5 \pm 7.0$ & $70.6 \pm 19.3$ & $88.8 \pm 27.5$ & $100.4 \pm 32.1$ \\
\hline & & $\% \Delta$ & 18.8 & -2.3 & -5.2 & -6.0 & -6.1 & 6.4 & 2.5 & 0.7 & -0.1 \\
\hline \multicolumn{3}{|l|}{ Treatment } & \multicolumn{9}{|l|}{$P$ value } \\
\hline \multicolumn{3}{|c|}{ Fertilizer $\mathrm{N}$ rate $(\mathrm{N})$} & 0.2907 & 0.6198 & 0.2528 & 0.4570 & 0.4632 & 0.4558 & 0.1721 & 0.2022 & 0.2713 \\
\hline \multicolumn{3}{|c|}{ Residue removal (R) } & $<0.0001$ & 0.9650 & 0.9933 & 0.1860 & 0.7150 & $<0.0001$ & $<0.0001$ & $<0.0001$ & $<0.0001$ \\
\hline \multicolumn{3}{|l|}{$\mathrm{N} \times \mathrm{R}$} & 0.2360 & 0.9221 & 0.9850 & 0.1861 & 0.7150 & 0.6746 & 0.6806 & 0.1876 & 0.2678 \\
\hline \multicolumn{3}{|l|}{ Year (Y) } & 0.0005 & 0.0884 & 0.2502 & 0.2087 & 0.2113 & 0.0058 & 0.1387 & 0.4771 & 0.7740 \\
\hline \multicolumn{3}{|l|}{$\mathrm{N} \times \mathrm{Y}$} & 0.0136 & 0.2435 & 0.0053 & 0.3910 & 0.0792 & 0.0811 & 0.0011 & 0.0319 & 0.0331 \\
\hline \multicolumn{3}{|l|}{$\mathrm{R} \times \mathrm{Y}$} & $<0.0001$ & 0.9650 & 0.9933 & 0.9670 & 0.9913 & $<0.0001$ & $<0.0001$ & $<0.0001$ & 0.0004 \\
\hline \multicolumn{3}{|c|}{$\mathrm{N} \times \mathrm{R} \times \mathrm{Y}$} & 0.2360 & 0.9221 & 0.9850 & 0.9668 & 0.9912 & 0.6746 & 0.6806 & 0.9065 & 0.9328 \\
\hline
\end{tabular}

removal. An increase of $2.9 \mathrm{Mg} \mathrm{ha}^{-1} \mathrm{SOC}$ was simulated with $35 \%$ removal. In the 0 to $90 \mathrm{~cm}$ increment under notillage, there was no change in SOC content with no residue removal, an increase with $35 \%$ residue removal, and a decrease with $70 \%$ residue removal. In the 0 to $120 \mathrm{~cm}$ increment under no-tillage, there was a decrease in SOC content with 0 or $70 \%$ residue removal and no change with $35 \%$ residue removal.

\section{Discussion}

Good agreement between CQESTR-simulated SOC content and measured SOC content over time has been documented in a number of other studies $[9,11,13,34,37]$. However, none of these studies have evaluated CQESTR under irrigated conditions, and only Gollany et al. [11, 13] evaluated the effect of residue removal. Liang et al. [9] validated CQESTR using soil $\mathrm{C}$ data from 13 experiments ranging from 20 to $>100$ years in duration and found that for 10 of the sites, lack of correlation (scatter) accounted for the largest percentage of MSD. The present study used SOC content data from two sites where treatments had been in place for 10 years. Over this time period, changes in SOC content were relatively small but simulated results agree well with measured changes in SOC content. For both sites, lack of correlation accounted for the largest percentage of MSD consistent with previous work. The present study differs from previous work in that soils were analyzed to $120 \mathrm{~cm}$, while previous studies were limited to 30 to $60 \mathrm{~cm}$ maximum depths.

The main objective of this study was to validate CQESTR in continuous corn systems over a range of management practices that included residue removal. For the rainfed site, Follett et al. [14] reported cumulative changes in SOC content for the 0 to 30 and 0 to $120 \mathrm{~cm}$ increments. For the 0 to $30 \mathrm{~cm}$ increment, they reported increases in SOC content from 1998 to 2007, with greater increases when no residue was removed than with residue removal and greater increases in SOC content at 180 than $120 \mathrm{~kg} \mathrm{~N}^{-1}$. Changes in simulated SOC content using CQESTR followed similar patterns in temporal and treatment responses (Table 1). For the 0 to $120 \mathrm{~cm}$ increment, Follett et al. [14] reported increases in cumulative SOC content for the $180 \mathrm{~kg} \mathrm{~N}^{-1}$ treatment but no increase for the $120 \mathrm{~kg} \mathrm{~N} \mathrm{ha}^{-1}$ treatment for both residue removal treatments. Similarly, CQESTR-simulated SOC content did not change from 1998 to 2007 in the $120 \mathrm{~kg} \mathrm{~N} \mathrm{ha}^{-1}$ treatment 
Table 2 CQESTR-simulated initial and final soil organic carbon (SOC) content (mean $\pm \mathrm{SEM}$ ) by tillage and residue removal treatments for an irrigated continuous corn site in eastern Nebraska

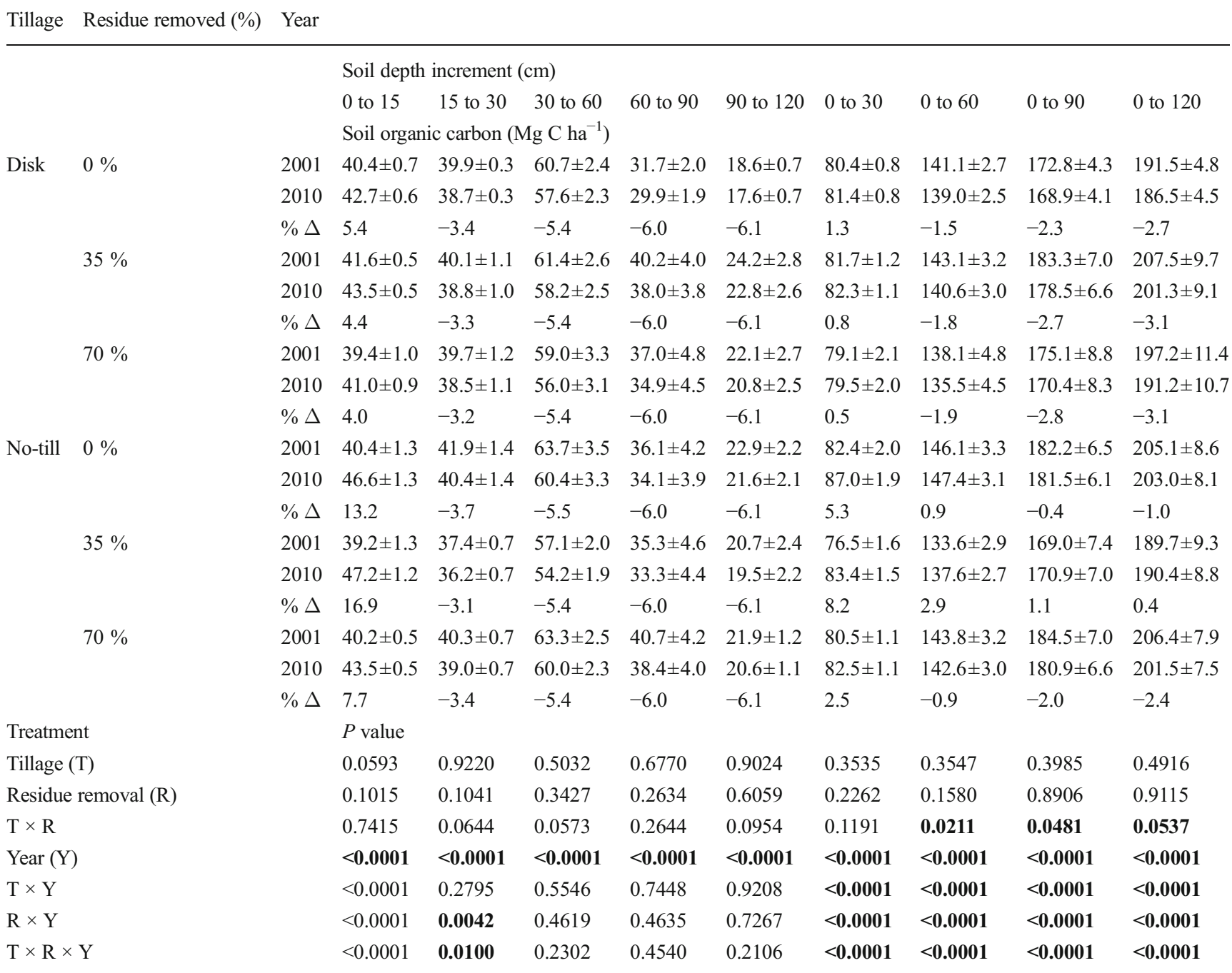

with or without reside removal and also did not change with residue removal in the $180 \mathrm{~kg} \mathrm{~N} \mathrm{ha}^{-1}$ treatment. In contrast, simulated SOC contents increased without residue removal in the $180 \mathrm{~kg} \mathrm{~N} \mathrm{ha}{ }^{-1}$ treatment compared to measured SOC contents (Table 1). At this site, conclusions regarding SOC content response to management based on CQESTR agree with those reported by Follett et al. [14]. This site is capable of supporting residue removal without reducing grain yield, and SOC increased with adequate fertilization and no-tillage.

For the irrigated site, Schmer et al. [28] reported year and residue removal differences in SOC content in the 0 to $30 \mathrm{~cm}$ increment, a tillage by residue removal by year interaction for SOC content in the 0 to $60 \mathrm{~cm}$ increment, and no differences in SOC content for the 0 to 90 and 0 to $120 \mathrm{~cm}$ increments. In the 0 to $30 \mathrm{~cm}$ increment, there was a loss of SOC from 2001 to 2010 and losses increased with residue removal. In the 0 to $60 \mathrm{~cm}$ increment, there was a loss of SOC in all residue removal treatments under disk tillage, little or no loss of SOC with medium or no residue removal, and loss of SOC under high residue removal under no-tillage. Detecting differences in SOC for the 0 to 90 or 0 to $120 \mathrm{~cm}$ increments is challenging due to high variability [8]. CQESTR simulated changes in SOC followed similar patterns, but there was less variation in the model results than in the measured values resulting in more differences being statistically significant. This also explains why a larger percentage of the MSD was attributed to a lack of correlation in the irrigated experiment than in the rainfed experiment. Conclusions drawn from the CQESTR simulation results are similar to those reported by Schmer et al. [28]. Under no-tillage, grain yields were reduced unless a portion of the residue was removed, and SOC increased with medium or no residue removal. Under disk tillage, grain yields were similar under all residue removal treatments, and SOC content decreased overall. 
The response to residue removal at the irrigated and rainfed sites was somewhat unexpected. We hypothesized that higher production under irrigation would allow for residue removal without negatively effecting yields or SOC stocks. Kochsiek et al. [16] compared decomposition of maize litter components in irrigated and rainfed systems for 3 years in eastern NE. They found that irrigation increased litter inputs, changed litter tissue quality, but not $\mathrm{C}$ allocation, and increased decomposition rate. After 3 years, irrigated and rainfed systems had similar $\left(110 \mathrm{~g} \mathrm{C} \mathrm{m}^{-1}\right)$ amounts of litter $\mathrm{C}$ remaining. Enhanced soil moisture under irrigation increases ecosystem respiration, eliminating any benefit of increased gross primary productivity and resulting in similar values for growing season net ecosystem productivity (NEP) between irrigated and rainfed fields [17]. Estimated NEP for irrigated corn was $441 \mathrm{~g} \mathrm{C}$ $\mathrm{m}^{-2}$ year ${ }^{-1}$ compared to $454 \mathrm{~g} \mathrm{C} \mathrm{m}^{-2}$ year $^{-1}$ for rainfed corn even though yields under irrigation $\left(12.9 \mathrm{Mg} \mathrm{ha}^{-1}\right)$ were greater than for rainfed $\left(8.2 \mathrm{Mg} \mathrm{ha}^{-1}\right)$ conditions [17]. Results from the current study suggest that CQESTR accurately accounts for the effect of soil moisture on soil processes affecting SOC changes.

At the irrigated site, high production levels required some type of residue management through stover removal or tillage to avoid yield reductions in subsequent years. However, high levels of residue removal under no-tillage or disk tillage across all residue treatments resulted in losses of SOC in the 0 to $60 \mathrm{~cm}$ depth increment. Our findings agree with those of [38] who compared changes in SOC stocks in irrigated corn under conventional or no-tillage in eastern Colorado and concluded that in that region, irrigation had a low potential for sequestering $\mathrm{C}$ especially under conventional tillage.

In this study, CQESTR accurately simulated SOC under a wide range of management practices. Use of process-based models such as CQESTR to evaluate management effects will be essential for sustaining the soil resource. As demand for food, feed, fiber, and feedstock increases, the need for predictive models that can guide soil management decisions will also increase.

Ethics Statement This research was conducted using appropriated USDA-ARS funds. Authors have no conflict of interest to report. There were no human or animal subjects used in this research.

\section{References}

1. Cassman KG (1999) Ecological intensification of cereal production systems: yield potential, soil quality, and precision agriculture. Proc Natl Acad Sci USA 96:5952-5959

2. Fedoroff NV, Battisti DS, Beachy RN, Cooper PJM, Fischhoff DA, Hodges CN, Knauf VC, Lobell D, Mazur BJ, Molden D, Reynolds MP, Ronald PC, Rosegrant MW, Sanchez PA, Vonshak A, Zhu J-K (2010) Radically rethinking agriculture for the 21 st century. Science 327:833-834
3. Garnett T, MC. Appleby, A. Balmford, IJ. Bateman, TG. Benton, P. Bloomer, B. Burlington, M. Dawkins, L. Dolan, D. Frazer, M. Herrero, I. Hoffmann, P. Smith, P.K. Thornton, C. Toulmin, S.J. Vermeulen, and H.C.J. Godfray (2013) Sustainable intensification in agriculture: Premises and policies. Science 341:33-34

4. Janzen HH (2005) Soil carbon: a measure of ecosystem response in a changing world? Can J Soil Sci 85:467-480

5. Schmidt MWI, Torn MS, Abiven S, Dittmar T, Guggenberger G, Janssens IA et al (2011) Persistence of soil organic matter as an ecosystem property. Nature 478:49-56

6. Six J, Elliot ET, Paustian K, Doran JW (1998) Aggregation and soil organic matter accumulation in cultivated and native grassland soils. Soil Sci Soc Am J 62:1367-1377

7. West TO, Post WM (2002) Soil organic carbon sequestration rates by tillage and crop rotation. Soil Sci Soc Am J 66:1930-1946

8. Kravchenko AN, Robertson GP (2011) Whole-profile soil carbon stocks: The danger of assuming too much from analyses of too little. Soil Sci Soc Am J 75:235-240

9. Liang Y, Gollany HT, Rickman RW, Albrecht SL, Follett RF, Wilhelm WW, Novak JM, Douglas CL Jr (2009) Simulating soil organic matter with CQESTR (v. 2.0): model description and validation against long-term experiments across North America. Ecol Model 220:568-581

10. Rickman RW, Douglas CL Jr, Albrecht SL, Bundy LG, Berc JL (2001) CQESTR: a model to estimate carbon sequestration in agricultural soils. J Soil Water Conserv 56:237-242

11. Gollany HT, Rickman RW, Liang Y, Albrecht SL, Machado S, Kang S (2011) Predicting agricultural management influence on long-term soil organic carbon dynamics: Implications for biofuel production. Agron J 103:234-246

12. Rasmussen PE, Goulding KWT, Brown JR, Grace PR, Janzen HH, Körschens M (1998) Long-term agroecosystem experiments: assessing agricultural sustainability and global change. Science 282:893-896

13. Gollany HT, Novak JM, Liang Y, Albrecht SL, Rickman RW, Follett RF, Wilhelm WW, Hunt PG (2010) Simulating soil organic carbon dynamics with residue removal using the CQESTR model. Soil Sci Soc Am J 74:372-383

14. Follett RF, Vogel KP, Varvel GE, Mitchell RB, Kimble J (2012) Soil carbon sequestration by switchgrass and no-till maize grown for bioenergy. Bio Energy Res 5:866-875

15. Rumpel C, Kögel-Knabner I (2011) Deep soil organic matter: a key but poorly understood component of terrestrial C cycle. Plant Soil 338:143-158

16. Kochsiek AE, Knops JMH, Walters DT, Arkebauer TJ (2009) Impacts of management on decomposition and the litter-carbon balance in irrigated and rainfed no-till agricultural systems. Agric For Meteorol 149:1983-1993

17. Verma SB, Dobermann A, Cassmann KG, Walters DT, Knops JM, Arkebauer TJ, Suyker AE, Burba GG, Amos B, Yang H, Ginting D, Hubbard KG, Gitelson AA, Walter-Shea EA (2005) Annual carbon dioxide exchange in irrigated and rainfed maize-based agroecosystems. Agric For Meteorol 131:77-96

18. Perlack RD, LL. Wright, AF. Turhollow, RL. Graham, BJ. Stokes, and.C Erbach (2005) Biomass as feedstock for a bioenergy and bioproducts industry: the technical feasibility of a billion-ton annual supply. DOE/GO-102005-2135 and ORNL/TM-205/66. Natl. Tech. Inf. Serv., Springfield, VA

19. Klopfenstein TJ, Erickson GE, Berger LL (2013) Maize is a critically important source of food, feed, energy, and forage in the USA. Field Crop Res 153:5-11

20. Wilhelm WW, Johnson JMF, Karlen DL, Lightle DT (2007) Corn stover to sustain soil organic carbon further constrains biomass supply. Agron J 99:1665-1667

21. Johnson JMF, Acosta-Martinez V, Cambardella CA, Barbour NW (2013) Crop and soil responses to using corn stover as a bioenergy 
feedstock: observations from the Northern US Corn Belt. Agriculture 3:72-89

22. Karlen DL, Varvel GE, Johnson JMF, Baker JM, Osborne SL, Novak JM, Adler PR, Roth GW, Birrell SJ (2011) Monitoring soil quality to assess the sustainability of harvested corn stover. Agron J 103:288-295

23. Blanco-Canqui H (2013) Crop residue removal for bioenergy reduces soil carbon pools: how can we offset carbon losses? Bio Energ Res 6:358-371

24. Muth DJ Jr, McCorkle DS, Koch JB, Bryden KM (2012) Modeling sustainable agricultural residue removal at the subfield scale. Agron J 104:970-981

25. Gregg JS, Izaurralde RC (2010) Effect of crop residue harvest on long-term crop yield, soil erosion and nutrient balance: trade-offs for a sustainable bioenergy feedstock. Biofuels 1:69-83

26. Janzen HH, Campbell CA, Izaurralde RC, Ellert BH, Juma NG, McGill WB, Zentner RP (1998) Management effects on soil C storage on the Canadian prairies. Soil Tillage Res 47:181-195

27. Wilhelm WW, Johnson JMF, Hatfield JL, Voorhees WB, Linden DR (2004) Crop and soil productivity response to corn residue removal: a literature review. Agron J 96:1-17

28. Schmer MR, Varvel GE, Follett RF, Jin VL, Wienhold BJ (2014) Tillage and residue management effects on soil carbon and nitrogen under irrigated continuous corn. Soil Sci Soc Am J 78:1987-1996

29. Varvel GE, Vogel KP, Mitchell RB, Follett RF, Kimble JM (2008) Comparison of corn and switchgrass on marginal soils for bioenergy. Biomass Bioenergy 32:18-21

30. Grossman R.B. and T.G. Reinsch (2002) Bulk density and linear extensibility. p. 201-228. In: Methods of soil analysis. Part 4: physical methods. SSSA, Madison, WI
31. Nelson DW, and L.E. Sommers (1996) Total carbon, organic carbon, and organic matter. p. 961-1010. In: Methods of soil analysis. Part 3: chemical methods. SSSA, Madison, WI

32. Renard KG, Foster GR, Weesies GA, McCool DK, Yoder DC (1996) Predicting soil erosion by water: a guide to conservation planning with the Revised Universal Soil Loss Equation (RUSLE). Agric. Handbk. 703. USDA, Washington, DC

33. Alvaro-Fuentes J, Lopez MV, Arrue JL, Moret D, Paustian K (2009) Tillage and cropping effects on soil organic carbon in Mediterranean semiarid agroecosystems: testing the century model. Agric Ecosyst Environ 134:211-217

34. Dalzell BJ, Johnson JMF, Tallaksen J, Allan DL, Barbour NW (2013) Simulated impacts of crop residue removal and tillage on soil organic matter maintenance. Soil Sci Soc Am J 77:1349-1356

35. Gauch HG Jr, Gene Hwang JT, Fick GW (2003) Model evaluation by comparison of model-based predictions and measured values. Agron J 95:1442-1446

36. Gbur E, Stroup W, McCarter K, Durham S, Young L, Christman M, West M, Kramer M (2012) Analysis of generalized linear mixed models in the agricultural and natural resources sciences. ASACSSA-SSSA, Madison, WI, p 283

37. Liang Y, Gollany HT, Rickman RW, Albrecht SL, Follett RF, Wilhelm WW, Novak JM, Douglas CL Jr (2008) CQESTR simulation of management practice effects on long-term soil organic carbon. Soil Sci Soc Am J 72:1486-1492

38. Follett RF, Jantalia CP, Halvorson AD (2013) Soil carbon dynamics for irrigated corn under two tillage systems. Soil Sci Soc Am J 77: 951-963 